OPEN ACCESS

Edited by:

Robert James Nicholls, University of East Anglia,

United Kingdom

Reviewed by:

Helena Granja,

University of Minho, Portugal

Rodolfo Silva,

National Autonomous University

of Mexico, Mexico

*Correspondence:

Molly Mitchell

molly@vims.edu

Specialty section:

This article was submitted to Coastal Ocean Processes, a section of the journal

Frontiers in Marine Science

Received: 20 November 2020 Accepted: 04 March 2021

Published: 22 March 2021

Citation:

Mitchell M, Isdell RE, Herman J and Tombleson C (2021) Impact Assessment and Management Challenges of Key Rural Human

Health Infrastructure Under Sea Level Rise. Front. Mar. Sci. 8:631757. doi: 10.3389/fmars.2021.631757

\section{Impact Assessment and} Management Challenges of Key Rural Human Health Infrastructure Under Sea Level Rise

\author{
Molly Mitchell*, Robert E. Isdell, Julie Herman and Christine Tombleson \\ Virginia Institute of Marine Science, William \& Mary, Gloucester Point, VA, United States
}

Accelerating sea level rise in Virginia, United States, will significantly increase the flooding threat to low-lying roads, residences, and critical infrastructure as well as raise the water table, allowing saltwater intrusion into well water and threatening the function of septic fields. Although most of the adaptation work in Virginia has focused on urban economic centers, the majority of the coastline is rural and faces different threats and opportunities to address them compared to urban areas due to their reduced economic assets and their reliance on private infrastructure. In this case study, we assess the potential for geospatially quantifying impact to septic systems and adjacent water ways due to sea level rise. The case study found that the data necessary to reliably quantify these impacts on a state-wide scale are lacking and collection of that information needs to be prioritized given the potential for extensive sea level impacts.

\footnotetext{
Keywords: sea level rise, human health, risk assessment, adaptation, climate change, septic, resilience
}

\section{INTRODUCTION}

Among long-term tide gage records, Virginia has one of the highest rates of sea level rise of any station on the East Coast, making the entire coastal area vulnerable to an increasing risk of "sunny day flooding" (flooding associated with high astronomic tides, rather than storm surge) and storm flooding. The shoreline of the mid-Atlantic coast of the United States is highly vulnerable to the effects of relative sea level rise (RSLR) due to changes in global sea level combined with regional and local land subsidence (Boon, 2012; Eggleston and Pope, 2013; Campbell and Wang, 2020) and shifts in the Gulf Stream current location and speed (Ezer, 2013). Sea level is rising in Norfolk, VA at a rate of $5.1 \mathrm{~mm} /$ year (compared to global sea level rise rates $\sim 3.2 \mathrm{~mm} /$ year; Church and White, 2011; Ezer, 2013) and that rate is accelerating at $0.119 \mathrm{~mm} /$ year $^{2}$ (Boon et al., 2018). This rate of acceleration has led to a $577 \%$ increase in flooding time in downtown Norfolk since the 1970s (Ezer and Atkinson, 2014). With these high rates of RSLR, and with evidence that those rates are accelerating (Sallenger et al., 2012; Boon and Mitchell, 2015; Boon et al., 2018), inundation is becoming an increasing concern both to ecological systems and built infrastructure. Currently, the impacts of storm-induced flooding added to long term RSLR on the natural landscape, local population, and built infrastructure are readily observable during nor'easters, hurricanes and even 
nuisance storms (Miller et al., 2013; Mitchell et al., 2013). Sea level rise will significantly increase the flooding threat to lowlying roads, residences, and critical infrastructure. It will also raise the water table, allowing saltwater intrusion into well water and threatening the function of septic fields. A study in Rhode Island found that groundwater levels were increasing 14-17 mm/year (Cox et al., 2019), which is far faster than sea level rise rates in that region (Boon et al., 2018).

In rural areas, an increased groundwater table will interfere with the function of the ubiquitous septic systems, causing serious damage to public health, water quality (WQ), and local fisheries (e.g., Katz et al., 2011; Macintosh et al., 2011; Withers et al., 2014). Failing septic systems result in an increased loading of bacteria, viruses, nitrogen and possibly phosphorus to adjacent waterways and are believed to represent about $6 \%$ of the total nitrogen load from the Chesapeake watershed (Bay Watershed Model 2009 Scenario, Chesapeake Bay TMDL). In small waterbodies, the local impact can be much higher. For example, in Buttermilk Bay, MA, United States $74 \%$ of the nitrogen was attributed to septic systems (Horsley Witten Hegeman Inc, 1991). Although, it has been suggested that a properly functioning septic system may remove phosphorus more effectively than a sewage treatment plant and might be a better option in areas where phosphorus contamination is an issue, and the water table is sufficiently low (Robertson et al., 2019). Where septic systems are at risk from high water tables, accelerating rates of sea level rise can cause impacts to increase dramatically. For example, in Miami (which currently has a lower rate of sea level rise than Virginia; Boon and Mitchell, 2015), approximately 1,000 properties with septic systems are already impacted by high water tables and they expect over 67,000 systems to be periodically compromised due to storms by 2040 (Miami Dade County, 2018). With accelerating sea level rise, failing septic systems will become a significant stressor to individual property owners, and may force them to retreat from the coastline, disrupting communities and creating significant economic losses both to the relocating population and the deserted localities.

Much consideration has been given to the impacts of sea level rise on urban areas and the significant costs associated with resilience efforts. However, globally, the majority of coastal populations live in rural areas, but have received limited attention (Small and Nicholls, 2003). To enhance resilience in these rural regions, we first need to understand the geospatial distribution of vulnerable septic systems and how those vulnerabilities may change overtime. Available data on the locations of existing septic systems are limited, due to the historical use of paper records. Only about 10 years of digital data currently exist in the Virginia Department of Health database on locations of installed septic systems.

\section{CONTEXT}

This study focused on rural areas in Virginia, United States (Figure 1). The Chesapeake Bay is located on the mid-Atlantic coast in Virginia (south) and Maryland (north) and is the largest estuary in the United States. There are approximately 11,500 kilometers of tidal shoreline in the Virginia portion of Chesapeake Bay. Coastal Virginia has 44 localities, with some urban centers, but a predominance of rural land use (residential, forested, and agriculture). Topography is low relief along much of the shoreline, but there are stretches of higher bluffs up the Bay tributaries.

The coastal region is underlain by marine sediments that are unconsolidated but well compacted. Soil types range from welldrained to poorly drained and primarily sand to primarily clay, depending upon location. In low-lying areas, the water table is relatively high.

\section{METHODS}

\section{Analysis of Septic Failures}

The first step of the case study analysis was to statistically analyze the geospatial distribution of septic system repair permits to find underlying patterns that could help inform decision-making using the Emerging Hot Spot Analysis tool in ArcGIS (ESRI, 2020). This tool looks at patterns across both spatial and temporal scales simultaneously. It can identify continuous hot spots (where there are constant and high numbers of repair permits) and emerging hot spots (locations representing new, intensifying, or diminishing clusters of repair permits). A full description of all types of hot spot classifications is available from ESRI ${ }^{1}$. Repair permit data for the years 2008-2018 were used, with a single temporal scale of one year. Data were aggregated within grid cells at a spatial scale of $1 \mathrm{~km}$. This spatial scale was selected as an appropriate management scale because the grids typically contained $>1$ house, so could show clusters, but were small enough for targeted management actions. Of the 19,753 grid cells that contained at least 1 house, the median number of houses was 17 (95\% of the cells had between 1 and 816 addresses, $7.8 \%$ of the cells had exactly 1 house/address).

The analysis was performed on both (1) the total number of repair permits within a cell and (2) the number of repair permits standardized to the total number of houses. These two approaches answer slightly different questions. The first approach locates the areas with the most repair permits recorded and tends to identify areas with a relatively high density of housing. Targeting these areas for mitigation measures would reduce overall issues under current conditions. The second approach highlights areas where there are unusually high failures relative to the housing density. It helps identify where failures are likely due to aging infrastructure, high groundwater tables, or other factors. Additional analyses to identify linkages between septic system failures and underlying geologic conditions were attempted using a maximum entropy machine learning approach implemented in the MaxEnt software (Phillips et al., 2021). Geologic data was obtained from the United States Department of Agriculture's National Resources Conservation Service Soil Service Geographic (SSURGO) soils database (Soil Survey Staff et al., 2012) and included features such as composition (percentages of sand,

\footnotetext{
${ }^{1}$ https://bit.ly/EHSA_ESRI
} 


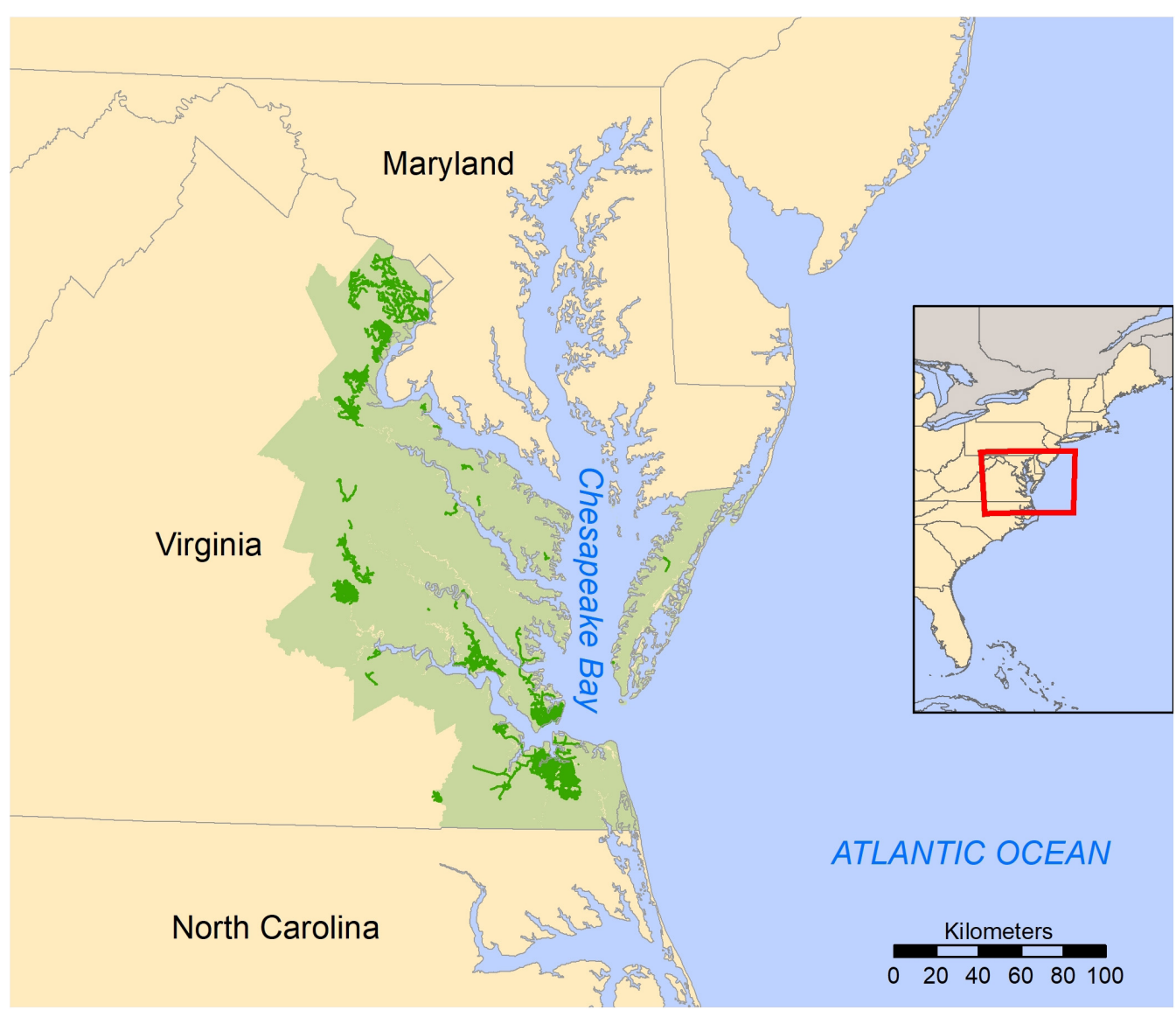

FIGURE 1 | Map of the study area, Virginia United States. Urban areas are designated by the sewer lines (shown in dark green) and were excluded from the study. All light green areas were included in the study.

silt, and clay), septic suitability, sediment saturation, and depth to water table. All factors were hypothesized to have a potential impact on the drainage efficiency and functionality of a septic system. Study-area-wide application of this analysis was abandoned after initial tests in subsets of the study area resulted in very poor predictive ability, with reduced predictive power as the size of the area under consideration increased. This was likely a result of the myriad and undocumented reasons for septic failure, chief among them being human error (e.g., putting things down their drains that they should not), combined with fairly coarse spatial resolutions in both the geologic and septic system data causing too much noise for the model to sort through and identify any clear correlations among septic failures and the underlying geology.

The results of analysis 1 (Tidewater hot spot results) suggest three basic issues are occurring. First, there are several areas where hotspots of septic failures occur annually (continuous hot spots). These may be areas with high groundwater tables that have low suitability for septic systems. Second, there are also several areas that have been hot spots in some years, but not others (sporadic hot spots). This may be due to high annual water tables associated with heavy rain or sea level variability or periodic episodes of aging septic systems. These areas are good targets for monitoring, particularly in heavy precipitation years and under sea level rise. Last, there are emerging hot spots, areas that should be investigated to see if conditions have changed or if systems are beginning to reach the end of their lifespan. Overall, 1,148 1-km grid cells were identified as hot spots of some kind. Hot spots were identified in most of the Tidewater localities where sewer is limited or unavailable and were prevalent in the areas surrounding the City of Richmond and in Gloucester County (Supplementary Figure 1).

The results of analysis two (high density failure areas) highlight $1 \mathrm{~km}$ grid cells where $>25 \%$ of the houses in the grid (minimum of five houses within the cell) had repair permits during the time of the analysis. High density failures were less common than hot spots, with a total of 72 grid cells. However, these areas are frequently located near water bodies or at the tops of creeks, where they have the potential to impact WQ in the immediate area. This proximity to the water is the only apparent pattern in the geographic dispersion of the high-density failure grids. This might suggest a connection between high groundwater tables and higher than expected need for repairs. This hypothesis would need to be tested specifically with data looking at groundwater tables in areas of high-density failures relative to surrounding areas to validate the connection. 


\section{Connection to Human Health and Fishery Safety}

To highlight areas where septic failures might be impacting human health and fisheries safety, or where repairs to septic systems might improve local WQ, we examined the results from the hot spot analysis in conjunction with WQ data from Virginia Department of Health's Division of Shellfish Safety.

Shellfish harvesting closure criteria were determined using WQ data and standard criteria for closure. This approach was used because it calculates a threshold of WQ at which shellfish in these waters are considered unsafe for human consumption. These levels would also indicate the potential for other environmental and human health issues. Two different metrics were calculated: the number of years in a 9-year period when the criteria for closure were met, and the annual trend in colony forming units (CFUs) of Escherichia coli in areas where the criteria for closure were met.

Years of closure were calculated using the Division of Shellfish Safety closure criteria where if the geometric mean of the previous 30 WQ measurements (approximately monthly) exceeds 14.0 CFUs or the 90th percentile exceeds 31.5 CFUs, the station and its surrounding waters are closed for shellfish harvest. The analysis was run on an annual interval from March 2012 to March 2020. After each run, the WQ station was classified as open or closed, and the number of all years in which the station was classified as closed were summed. Of the 2,254 stations, 2,121 stations had enough data to run the analysis. The number of stations that were closed for N out of nine possible years are provided in Table 1.

The annual trend in CFUs looked at the trend in WQ at a station over a 9-year period. Based on the calculated geometric mean CFU values for each station, we ran a simple linear regression in $\mathrm{R}$ [function $\operatorname{lm}($ ), $\mathrm{R}$ Development Core Team, 2019] for each station through time (2012-2020) to see if there was a significant $(\alpha=0.05)$ positive trend in the number of CFUs. Among the 2,121 stations, 1,370 had significant positive trends (increasing annual CFUs) and 22 had significant negative trends (decreasing annual CFUs). Stations which were both classified as closed in 2020 and had significant positive trends in CFUs ( $n=471$; subset in Figure 2) were selected for a geospatial overlap analysis (intersect in ArcGIS Pro). Results of

TABLE 1 | The 2,121 water quality monitoring stations from the Virginia Division of Shellfish Safety were classified as closed or open for shellfish harvesting each year from 2012 to 2020 and the total number of years they were closed were summed.

\begin{tabular}{lc}
\hline Years closed & Stations \\
\hline 0 & 1087 \\
1 & 138 \\
2 & 103 \\
3 & 80 \\
4 & 70 \\
5 & 83 \\
6 & 60 \\
7 & 59 \\
8 & 75 \\
9 & 366
\end{tabular}

the analysis identifies only one incident where a low WQ region overlapped directly with a septic hot spot in Tidewater Virginia. This emphasizes the difficulty in trying to correlate septic repair permits and potential environmental impacts. Neither dataset was collected specifically for the purpose of making these types of connections and therefore any correlation should be viewed with extreme caution.

\section{Consideration of Future Conditions}

As sea level rises, so too will the groundwater. As groundwater is typically at or above sea level unless there is significant withdrawal, increases in groundwater table elevation as a result of sea level rise are likely to negatively impact the efficiency of septic drain fields long before direct inundation. Since there are no large spatial models of groundwater in Virginia nor its potential to change with sea level rise, we instead mapped the areas whose elevations are less than three feet $(\sim 1 \mathrm{~m})$ above mean sea level (MSL) at the current time and under projected sea level rise (Sweet et al., 2017, Intermediate Scenario). The Intermediate Scenario was chosen because it most closely aligns with historic tide-gage data analysis and projections for coastal Virginia (Boon et al., 2018). Elevations used were:

$$
\begin{aligned}
& \text { Current }=0 \mathrm{ft} \mathrm{NAVD} 88+3 \mathrm{ft} \\
& 2040=1.4 \mathrm{ft} \mathrm{NAVD} 88+3 \mathrm{ft} \\
& 2080=3.16 \mathrm{ft} \mathrm{NAVD} 88+3 \mathrm{ft}
\end{aligned}
$$

Hot spots were geographically analyzed for overlap with MSL +3 feet in the current time frame to identify areas where hot spots might be driven by high water tables.

Results (Table 2) show that between a quarter and a third of Consecutive and Sporadic hot spots are located in areas with potentially high-water tables. Interestingly, a similar number of diminishing hot spots are also located in these areas, making it difficult to draw any firm conclusions about the connection of groundwater to the different types of hot spots.

\section{DISCUSSION}

The key limitation in assessing the vulnerability of septic systems to failure was a lack of data collected specifically for this purpose. Important information, such as system age, siting, design and maintenance history were essentially unknown, an issue not limited to Virginia or the United States (Withers et al., 2012, 2014). Most information that exists on septic systems is collected for permitting or regulatory purposes. For this case study, we utilized a septic repair permit database from the Virginia Department of Health. This dataset allowed us to analyze clusters of failures; however, it was created for regulatory purposes and conclusions drawn from it require some critical caveats:

- The data do not necessarily represent the total number of septic failures because there may be currently unidentified issues. This means that repair permits could underestimate the total problem. This also could lead to geographic 


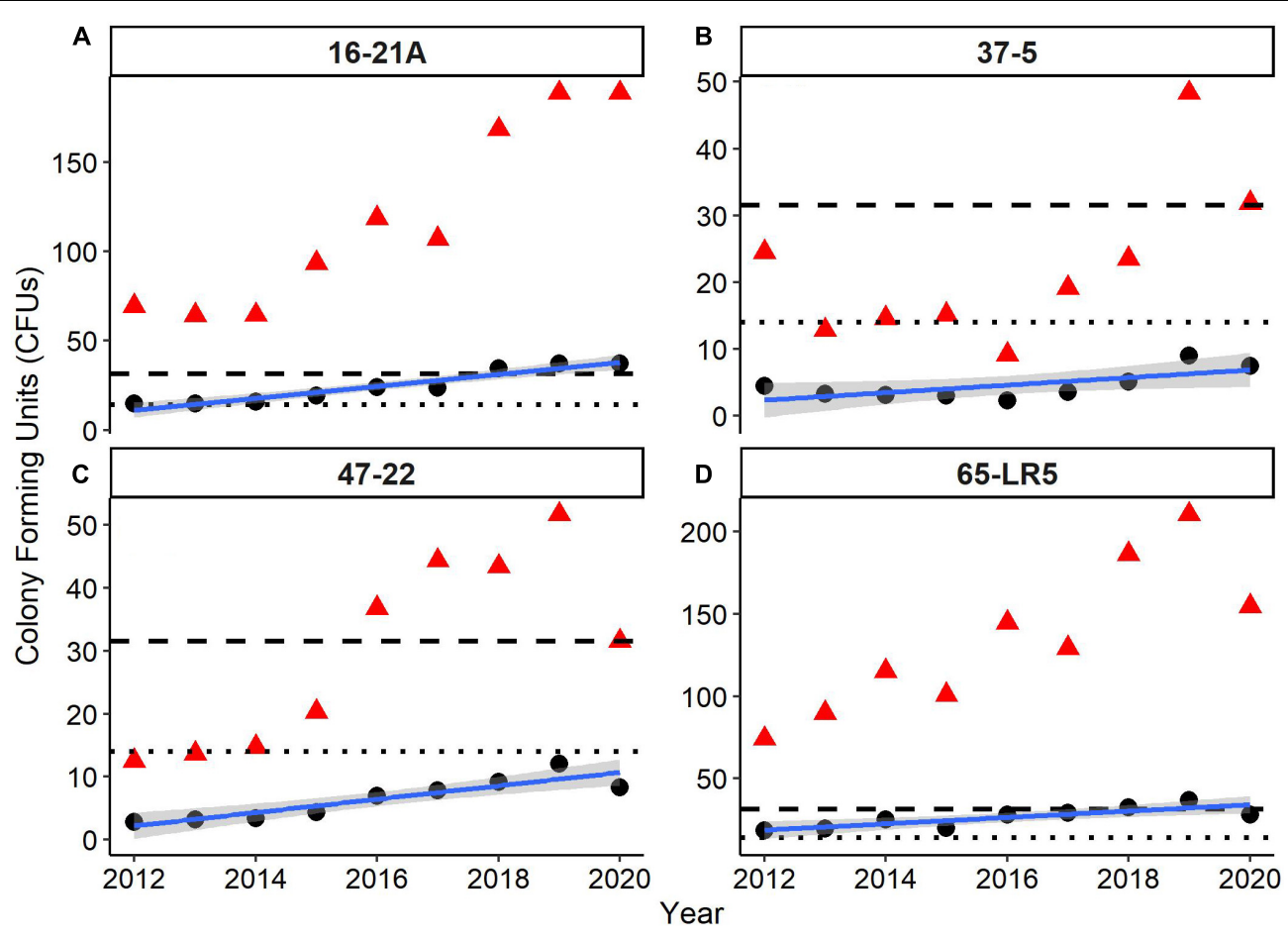

FIGURE 2 | The number of Escherichia coli colony forming units (CFUs) for four water quality monitoring sites spread throughout the Chesapeake Bay from 2012 to 2020. The annual geometric mean (black circle) and its trend line (solid blue line) along with the estimated 90th percentile (red triangle) are provided with horizontal lines representing the closure thresholds for an annual geometric mean (dotted; 14 CFUs) and the 90th percentile (dashed; 31.5 CFUs). Station names are provided above each plot. Each of the displayed stations had significant $(\alpha=0.05)$ positive trends and were closed in 2020. Panels (A) and (D) exceeded both thresholds, while panels (B) and (C) only exceeded the 90th percentile.

discrepancies in spatial patterns of failures if socioeconomic factors affect the likelihood that a septic issue is identified and repaired.

- The data does not necessarily represent the total number of septic failures because it does not record the degree of severity of the problem resulting in the repair. This could mean that the repair permits are equally counting minor issues and severe drain field failures, which means the data could overestimate the total problem. This leads to an additional caveat, that the repair permits do not distinguish the reason for the repair. Areas with high numbers of septic failures could be due to all of the systems aging simultaneously or could be due to rising groundwater tables. In areas in close proximity to the waterfront, we believe it is reasonable to assume that these clusters of failures could be related to groundwater tables, and that these areas should be targets for environmental monitoring.

- Repair permits are attached to street addresses. On large parcels, the actual drain field can be some distance from the spatially located street address. Therefore, potential explanatory variables (such as the underlying soil conditions, groundwater levels, and proximity to waterways) cannot be extracted from other data sets and connected with repair permits with a high level of confidence. Broad generalizations can be made but should be used cautiously.
- Dates on repair permits reflect an ambiguous time between when the issue occurred and when the issue was fixed. Temporal connections between septic issues and environmental impacts (such as adjacent WQ) cannot be made with a high level of confidence due to the time lag between contamination and potential for detection (Katz et al., 2011, Withers et al., 2012). Broad generalizations can be made but should be used cautiously.

- The age of septic systems is known to be a factor in septic system failure. Construction permits for systems often occur prior to house or neighborhood construction and use tax parcel and lot numbers for permit location rather than addresses. Although this information can be used to locate the parcel the septic is on, it must be done individually, and a researcher cannot take advantage of the automated geocoding processes. Locating these sites individually is time-intensive; therefore, incorporating septic system age into an analysis would be very expensive. Detailed information about the hydraulic networks, such as the vertical distance of the septic tanks above the groundwater table at the time of installation, is not always known. This measure is one of the key variables affecting nutrient and pathogen contamination of groundwater, and by extension, adjacent waterways (Harris, 1995). Newly saturated septic drain fields, associated with sea level rise, have been shown to increase fecal coliform bacteria in 
TABLE 2 | Hot spots potentially related to high groundwater table.

\begin{tabular}{lccc}
\hline Pattern & Total number & $\begin{array}{c}\text { Number in } \\
\text { MSL + 3ft }\end{array}$ & $\begin{array}{c}\text { \% in } \\
\text { MSL + 3ft }\end{array}$ \\
\hline Consecutive hot spot & 265 & 78 & 29.43 \\
Diminishing hot spot & 54 & 13 & 24.07 \\
Historical hot spot & 83 & 2 & 9.38 \\
Intensifying hot spot & 32 & 3 & 9.38 \\
Persistent hot spot & 172 & 23 & 13.37 \\
Sporadic hot spot & 542 & 146 & 26.94 \\
Overall & 1148 & 265 & 23.08 \\
\hline
\end{tabular}

output waters (Cooper et al., 2016) and could result in decreasing creek WQ over time. Coastal properties where septic tanks only met minimum standards ( $3 \mathrm{ft}$ above the water table) at the time of installation have a higher probability of impacts from rising groundwater than tanks installed with more vertical space.

Although is it critical to understand the impacts of future sea level rise and increased rainfall intensity, duration, and frequency on septic system failure, the caveats listed above preclude the use of predictive modeling in the region of this case study. In addition, the regulatory structure of both the septic repair database and the shellfish closure database limit analyses to correlative measures, restricting conclusions that can be drawn from the analyses. Previous studies have shown that septic systems cause bacterial contamination of groundwater (e.g., Stewart and Reneau, 1981; Arnade, 1999), but that definitively connecting bacterial concentrations in estuarine creeks to failing septic systems on a broad scale can be difficult (Cahoon et al., 2006) perhaps in part due to tidal flushing or the prevalence of tidal marshes (Giordano et al., 2011). We suspect the limited existence of data necessary to connect septic systems with human health risks is a wide-spread issue throughout coastal areas. We recommend concerted efforts to build datasets specific to understanding changes in rural infrastructure and connections to the critical issues such as human and ecological health to improve the resiliency of rural areas under sea level rise.

Understanding the geographical scope and the potential financial resources necessary to address rural septic issues under accelerating sea level rise will be critical to finding a solution. Supplementary Figure 2 shows a DASIR (Driver-Activity-StateImpact-Responses) framework for coastal septic issues; these frameworks have been found to be a useful approach to analyze and explain human-environmental relationships and help lead to management actions (Patrício et al., 2016). In this framework, there is a basic need for waste management (Driving Force) that will continue. Management actions should focus on removing the waste management systems from potential interactions with groundwater. This can be addressed using alternative, aboveground, or mounded septic systems (Macintosh et al., 2011) or through centralized wastewater treatment systems (such as sewer systems or community septic systems). The best approach for managing this issue will depend on the financial resources available and the political and cultural aspects of the community.
Although this study focused on rising groundwater impacts to septic fields, the majority of the properties included also use private wells, so sea level rise impacts in rural areas may go beyond failing septic systems. Contamination from failing septic systems can be carried to adjacent wells, polluting the drinking water (e.g., Hickey and Duncan, 1966; Murphy et al., 2020). Salinization of drinking water is also a growing threat from sea level rise due to its serious effect on human health (Tully et al., 2019). Saltwater intrusion into well water requires water treatment or abandonment of the well and has been the documented cause for the closure of hundreds of drinking wells in coastal areas such as Cyprus, Mexico, Oman, and Israel (Barlow and Reichard, 2010). In Virginia, the extent of salinity intrusion into well water is not known; however, the information available suggests that it could be a significant issue. In 2019, sodium contamination was documented in approximately $30 \%$ of the 2,300 tested private water wells across Virginia (VAHWQP, 2019). In certain coastal localities those numbers are much higher. For example, in Isle of Wight County $83 \%$ of tested wells have sodium contamination and on the Eastern Shore of Virginia contamination was found in $43 \%$ of tested wells (VAHWQP, 2017). Sea level rise is expected to cause an increase in groundwater salinity throughout most of the Eastern Shore of Virginia, resulting in impacts to private drinking wells in multiple locations (Sanford et al., 2009).

\section{CONCLUSION}

Despite the limitations of this case study, this type of analysis can still inform decision making and improve rural resilience. In coastal Virginia, where rural governments typically have limited financial resources, rural homeowners are frequently responsible for any adaptation costs on their individual properties, including both installation of new septic systems and maintenance of existing systems. Analyses such as the ones in this project can position individual homeowners to potentially receive funding available for septic adaptations. In addition, if areas of high vulnerability for septic systems can be targeted, Virginia has state programs that can help to fund community adaptations. The development of more targeted datasets and enhanced sea level rise-groundwater models will allow for an improved understanding of the future vulnerabilities of the vast rural septic infrastructure at risk from sea level rise.

\section{DATA AVAILABILITY STATEMENT}

The raw data supporting the conclusions of this article will be made available by the authors, without undue reservation.

\section{AUTHOR CONTRIBUTIONS}

MM, RI, JH, and CT all contributed to the design of the case study, and analysis, and the final manuscript. RI and CT did the primary data cleaning and analysis. MM drafted the 
manuscript. All authors contributed to the article and approved the submitted version.

\section{FUNDING}

The authors would like to acknowledge the Virginia Department of Health for funding of the project.

\section{ACKNOWLEDGMENTS}

The authors would like to acknowledge the Virginia Department of Health for collaboration in providing data for the analysis. This

\section{REFERENCES}

Arnade, L. J. (1999). Seasonal correlation of well contamination and septic tank distance. Groundwater 37, 920-923. doi: 10.1111/j.1745-6584.1999.tb01191.x

Barlow, P. M., and Reichard, E. G. (2010). Saltwater intrusion in coastal regions of North America. Hydrogeology Journal 18, 247-260. doi: 10.1007/s10040-0090514-3

Boon, J. D. (2012). Evidence of sea-level acceleration at US and Canadian tide stations, Atlantic Coast, North America. Journal of Coastal Research 28, 14371445. doi: $10.2112 /$ jcoastres-d-12-00102.1

Boon, J. D., and Mitchell, M. (2015). Nonlinear Change in Sea Level Observed at North American Tide Stations. Journal of Coastal Research 316, 1295-1305. doi: 10.2112/JCOASTRES-D-15-00041.1

Boon, J. D., Mitchell, M., Loftis, J. D., and Malmquist, D. M. (2018). Anthropocene Sea Level Change: A History of Recent Trends Observed in the U.S. East, Gulf, and West Coast Regions, Special Report in Applied Marine Science and Ocean Engineering (SRAMSOE) No. 467. Virginia Institute of Marine Science, William \& Mary.

Cahoon, L. B., Hales, J. C., Carey, E. S., Loucaides, S., Rowland, K. R., and Nearhoof, J. E. (2006). Shellfishing closures in southwest Brunswick County, North Carolina: Septic tanks vs. storm-water runoff as fecal coliform sources. Journal of Coastal Research 22, 319-327. doi: 10.2112/03-0028.1

Campbell, A. D., and Wang, Y. (2020). Salt marsh monitoring along the midAtlantic coast by Google Earth Engine enabled time series. PLoS ONE 15:e0229605. doi: 10.1371/journal.pone.0229605

Church, J. A., and White, N. J. (2011). Sea-level rise from the late 19th to the early 21st century. Surveys in geophysics 32, 585-602. doi: 10.1007/978-94-0072063-3_17

Cooper, J. A., Loomis, G. W., and Amador, J. A. (2016). Hell and high water: Diminished septic system performance in coastal regions due to climate change. PloS one 11:e0162104. doi: 10.1371/journal.pone.0162104

Cox, A. H., Loomis, G. W., and Amador, J. A. (2019). Preliminary evidence that rising groundwater tables threaten coastal septic systems. Journal of Sustainable Water in the Built Environment 5, 04019007. doi: 10.1061/jswbay.0000887

Eggleston, J., and Pope, J. (2013). Land subsidence and relative sea-level rise in the southern Chesapeake Bay region: U.S. Geological Survey Circular. 1392.

ESRI (2020). ArcGIS Pro. Redlands, CA: Environmental Systems Research Institute.

Ezer, T. (2013). Sea level rise, spatially uneven and temporally unsteady: Why the U.S. East Coast, the global tide gauge record, and the global altimeter data show different trends. Geophys. Res. Lett. 40, 5439-5444. doi: 10.1002/2013GL057952

Ezer, T., and Atkinson, L. P. (2014). Accelerated flooding along the US East Coast: on the impact of sea-level rise, tides, storms, the Gulf Stream, and the North Atlantic oscillations. Earth's Future 2, 362-382. doi: 10.1002/2014ef000252

Giordano, J. C. P., Brush, M. J., and Anderson, I. C. (2011). Quantifying annual nitrogen loads to Virginia's coastal lagoons: sources and water quality response. Estuaries and Coasts 34, 297-309. doi: 10.1007/s12237-010-9345-7

Harris, P. J. (1995). Water quality impacts from on-site waste disposal systems to coastal areas through groundwater discharge. Environmental Geology 26, 262-268. doi: 10.1007/bf00770477 manuscript is Contribution No. 4000 of the Virginia Institute of Marine Science, William \& Mary.

\section{SUPPLEMENTARY MATERIAL}

The Supplementary Material for this article can be found online at: https://www.frontiersin.org/articles/10.3389/fmars. 2021.631757/full\#supplementary-material

Supplementary Figure 1 | Example of results from the Tidewater Hot Spot analysis, focused on two areas with high concentration of repair permit hot spots. The different categories of hot spots are shown in the legend.

Supplementary Figure 2 | A DASIR (Driver-Activity-State-Impact-Responses) framework for septic issues under sea level rise.

Hickey, J. L., and Duncan, D. L. (1966). Performance of single family septic tank systems in Alaska. Journal (Water Pollution Control Federation) 12981309.

Horsley Witten Hegeman Inc (1991). Quantification and control of nitrogen inputs to Buttermilk Bay, Vol. Vol I. Barnstable, Massachusetts. Report: 32.

Katz, B. G., Eberts, S. M., and Kauffman, L. J. (2011). Using $\mathrm{Cl} / \mathrm{Br}$ ratios and other indicators to assess potential impacts on groundwater quality from septic systems: a review and examples from principal aquifers in the United States. $J$ Hydrol 397, 151-166. doi: 10.1016/j.jhydrol.2010.11.017

Macintosh, K. A., Jordan, P., Cassidy, R., Arnscheidt, J., and Ward, C. (2011). Low flow water quality in rivers: septic tank systems and high-resolution phosphorus signals. Sci Total Environ 412, 58-65. doi: 10.1016/j.scitotenv.2011. 10.012

Miami Dade County (2018). Septic Systems Vulnerable To Sea Level Rise. Report. 66. https://www.miamidade.gov/green/library/vulnerability-septic-systems-sealevel-rise.pdf (accessed January 22, 2021).

Miller, K. G., Kopp, R. E., Horton, B. P., Browning, J. V., and Kemp, A. C. (2013). A geological perspective on sea-level rise and its impacts along the U.S.mid-Atlantic coast. Earth's Future 1, 3-18. doi: 10.1002/2013EF00 0135

Mitchell, M., Hershner, C., Herman, J., Schatt, D. E., Eggington, E., and Center for Coastal Resources Management (2013). Recurrent flooding study for Tidewater Virginia. Virginia Institute of Marine Science, William \& Mary.

Murphy, H. M., McGinnis, S., Blunt, R., Stokdyk, J., Wu, J., Cagle, A., et al. (2020). Septic Systems and Rainfall Influence Human Fecal Marker and Indicator Organism Occurrence in Private Wells in Southeastern Pennsylvania. Environmental Science \& Technology 54, 3159-3168. doi: 10.1021/acs.est. $9 \mathrm{~b} 05405$

Patrício, J., Elliott, M., Mazik, K., Papadopoulou, K. N., and Smith, C. J. (2016). DPSIR-two decades of trying to develop a unifying framework for marine environmental management? Frontiers in Marine Science 3:177.

Phillips, S. J., Dudík, M., and Schapire, R. E. (2021). [Internet] Maxent software for modeling species niches and distributions (Version 3.4.1). Available from url: http://biodiversityinformatics.amnh.org/open_source/maxent/. Accessed on 2021-1-21

R Development Core Team (2019). R: A language and environment for statistical computing. Vienna, Austria: R Foundation for Statistical Computing. Available online at: http://www.R-project.org/ (accessed November 14, 2020).

Robertson, W. D., Van Stempvoort, D. R., and Schiff, S. L. (2019). Review of phosphorus attenuation in groundwater plumes from 24 septic systems. Science of The Total Environment 692, 640-652. doi: 10.1016/j.scitotenv.2019.07.198

Sallenger, A. H., Doran, K. S., and Howd, P. A. (2012). Hotspot of accelerated sealevel rise on the Atlantic coast of North America. Nature Climate Change 2, 884-888. doi: $10.1038 /$ nclimate 1597

Sanford, W. E., Pope, J. P., and Nelms, D. L. (2009). Simulation of groundwaterlevel and salinity changes in the Eastern Shore, Virginia: U.S. Geological Survey Scientific Investigations Report 2009-5066. 125.

Small, C., and Nicholls, R. J. (2003). A global analysis of human settlement in coastal zones. Journal of coastal research 584-599. 
Soil Survey Staff, Natural Resources Conservation Service, and United States Department of Agriculture (2012). Web Soil Survey. Available online at https: //websoilsurvey.nrcs.usda.gov/. Accessed [Jan/2021].

Stewart, L. W., and Reneau, R. B. Jr. (1981). Spatial and Temporal Variation of Fecal Coliform Movement Surrounding Septic Tank-Soil Absorption Systems in Two Atlantic Coastal Plain Soils. Journal of Environmental Quality 10, 528-531. doi: 10.2134/jeq1981.00472425001000040022x

Sweet, W. V., Kopp, R. E., Weaver, C. P., Obeysekera, J., Horton, R. M., Thieler, E. R., et al. (2017). Global and Regional Sea Level Rise Scenarios for the United States. NOAA Technical Report NOS CO-OPS 083. NOAA/NOS Center for Operational Oceanographic Products and Services.

Tully, K., Gedan, K., Epanchin-Niell, R., Strong, A., Bernhardt, E. S., BenDor, T., et al. (2019). The invisible flood: The chemistry, ecology, and social implications of coastal saltwater intrusion. BioScience 69, 368-378.

VAHWQP (2017). Virginia Household Water Quality Program data 2011-2017. https://www.wellwater.bse.vt.edu/resources.php (accessed January 15, 2021).

VAHWQP (2019). Virginia Household Water Quality Program 2019 Annual Report. https://www.wellwater.bse.vt.edu/files/2019VAHWQP-Annual-Report. pdf (accessed January 15, 2021).
Withers, P. J., Jordan, P., May, L., Jarvie, H. P., and Deal, N. E. (2014). Do septic tank systems pose a hidden threat to water quality? Frontiers in Ecology and the Environment 12:123-130. doi: 10.1890/130131

Withers, P. J. A., May, L., Jarvie, H. P., Jordan, P., Doody, D., Foy, R. H., et al. (2012). Nutrient emissions to water from septic tank systems in rural catchments: Uncertainties and implications for policy. Environmental Science \& Policy 24, 71-82. doi: 10.1016/j.envsci.2012.07.023

Conflict of Interest: The authors declare that the research was conducted in the absence of any commercial or financial relationships that could be construed as a potential conflict of interest.

Copyright (c) 2021 Mitchell, Isdell, Herman and Tombleson. This is an open-access article distributed under the terms of the Creative Commons Attribution License (CC BY). The use, distribution or reproduction in other forums is permitted, provided the original author(s) and the copyright owner(s) are credited and that the original publication in this journal is cited, in accordance with accepted academic practice. No use, distribution or reproduction is permitted which does not comply with these terms. 